E

51

.1393

no. 32

NMAI

NDIAN NOTES

) MONOGRAPHS

EdITEd By F. W. Hodge

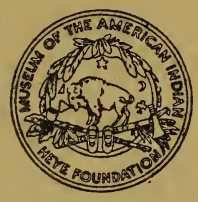

A SERIES OF PUBLICATIONS REI_ATING TO THE AMERICAN ABORIGINES

\title{
GUIDE TO THE COLLECTIONS \\ FROM THE WEST INDIES
}

NEW YORK

MUSEUM OF THE . AMERICAN INDIAN

HEYE FOUUNDATION

1922 
Thus series of Indian Notes AND MonoGRAPHS is devoted primarily to the publica. tion of the results of studies by members of the staff of the Museum of the American Indian, Heye Foundation, and is uniform with Hispanic Notes aNd MonograpHs, published by the Hispanic Society of America, with which organization this Museum is in cordial coopperation.

Only the first ten volumes of INDLAN Notes AND MONOGRAPHS are numbered. The unnumbered parts may readily be determined by consulting the List of Publications issued as one of the series. 
N.

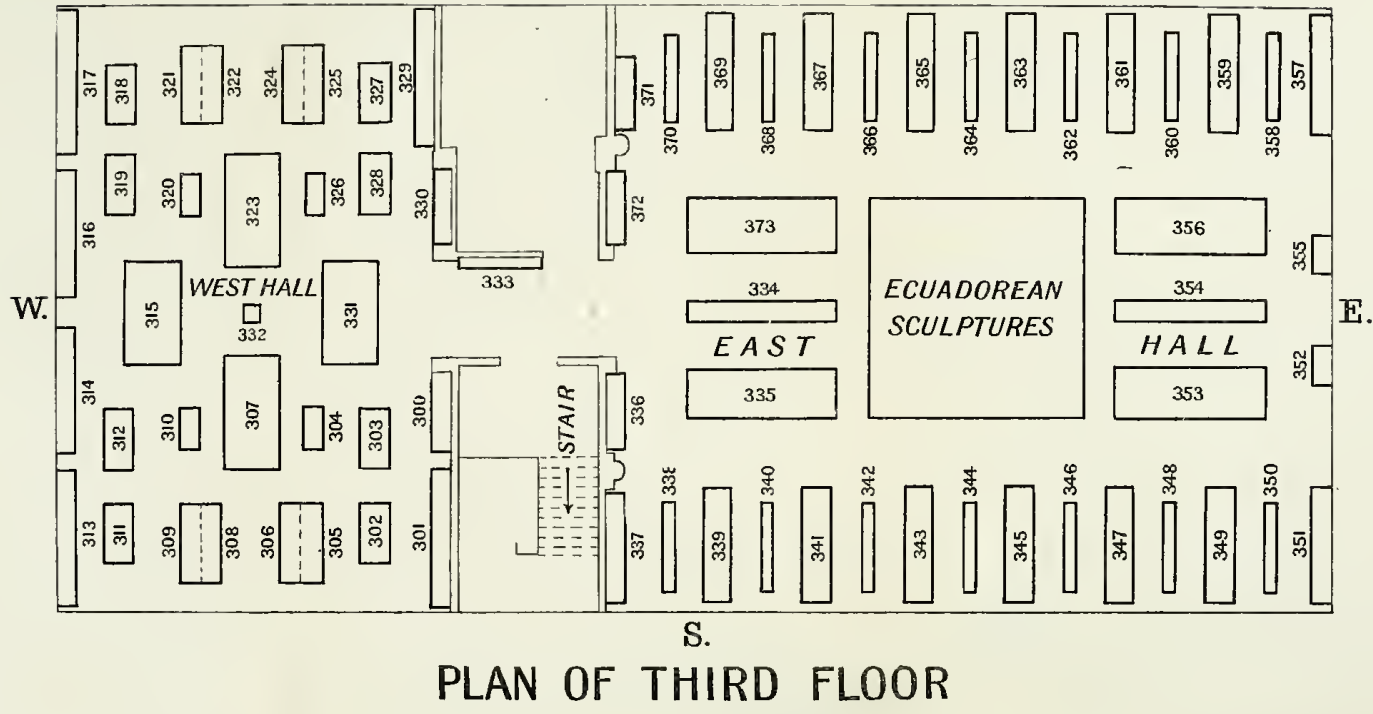






\section{INDIAN NOTES AND MONOGRAPHS \\ Edited by F. W. Hodge}

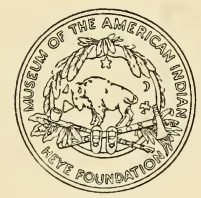

A SERIES OF PUBLICATIONS RELATING TO THE AMERICAN ABORIGINES

\section{GUIDE TO THE COLLECTIONS}

\section{FROM THE WEST INDIES}

NEW YORK

MUSEUM OF THE AMERICAN INDIAN HEYE FOUNDATION 
SMITHSONIAN

ULLL 172010

LIBRARIES 


\begin{tabular}{|c|c|}
\hline & 3 \\
\hline \multicolumn{2}{|l|}{ CONTENTS } \\
\hline PAGE & \\
\hline Native Population............... 5 & \\
\hline The Taino tribes.............. 9 & \\
\hline The Ciboney................ 13 & \\
\hline The Carib................... 16 & \\
\hline Ethnology of the West Indies......... 17 & \\
\hline Archeology of the West Indies......... 18 & \\
\hline Cuba...................... 18 & \\
\hline Jamaica................... 22 & \\
\hline Bahamas.................... 24 & \\
\hline Santo Domingo................. & \\
\hline Porto Rico................ 27 & \\
\hline Virgin Islands. . . . . . . . . . . . & \\
\hline Other Islands................ 31 & \\
\hline Guadaloupe and Dominica.......... 32 & \\
\hline Martinique................... 32 & \\
\hline Santa Lucia.................. 33 & \\
\hline Saint Vincent................. 33 & \\
\hline Grenadines.................. 35 & \\
\hline Grenada................... 36 & \\
\hline Trinidad .................... 36 & \\
\hline Tobago..................... 37 & \\
\hline Barbadoes.................... 38 & \\
\hline I N I A N NOTES & \\
\hline
\end{tabular}





\begin{tabular}{|} 
THE WEST INDIES \\
NATIVE PopuLATION \\
an Indians of the Antilles possess \\
terest in view of the fact that \\
they were the first of the Ameri- \\
can aborigines to meet the white invader \\
from overseas, and the first to lose their \\
lands and to suffer virtual extermination \\
at his hands. Columbus, and the early \\
explorers following in his wake, found the \\
Bahamas and the Greater Antilles (Cuba, \\
Haiti, Porto Rico, and Jamaica) inhabited \\
for the larger part by a number of peaceable \\
agricultural tribes speaking similar dialects \\
of the Arawak language, now grouped by \\
students under the name of Taino. In the \\
large islands of Cuba and Haiti were also \\
found a very primitive group of Indians, \\
in Cuba called Ciboney, which, although \\
apparently at one period occupying large \\
I N D I A N N O T E S
\end{tabular}




\begin{tabular}{|l|l|}
\hline 6 & \multicolumn{1}{|c|}{ G U I D E } \\
\hline $\begin{array}{l}\text { areas-the whole of Cuba, for instance,- } \\
\text { by the time of the discovery survived only } \\
\text { in certain isolated districts. These savages } \\
\text { lived largely in caves, subsisting on natural } \\
\text { products, without knowledge of agriculture, } \\
\text { and were able to manufacture objects of } \\
\text { only the simplest and crudest kinds. } \\
\text { The Lesser Antilles were found to be } \\
\text { occupied by a third group, the Carib, a } \\
\text { fierce and bloodthirsty people whose con- } \\
\text { tinual piratical raids and notorious canni- } \\
\text { balism struck terror to the hearts of their } \\
\text { more peaceable neighbors. In spite of } \\
\text { this, they seem to have practised agricul- } \\
\text { ture, and were nearly as far advanced in } \\
\text { the arts as the Taino tribes. } \\
\text { The origin of the Ciboney, apparently the } \\
\text { earliest inhabitants of Cuba, Haiti Santo } \\
\text { Domingo), and perhaps of other islands, } \\
\text { is lost in the mists of the past. As yet there } \\
\text { is no evidence to connect them with the } \\
\text { tribes of North, Central, or South America. } \\
\text { We have every reason for believing, how- } \\
\text { ever, that both the Arawak and the Carib } \\
\text { migrated to the islands from South America, } \\
\text { where many tribes speaking related dialects }\end{array}$ \\
\hline \begin{tabular}{l} 
I N I A N N O T E S \\
\hline
\end{tabular} \\
\hline
\end{tabular}




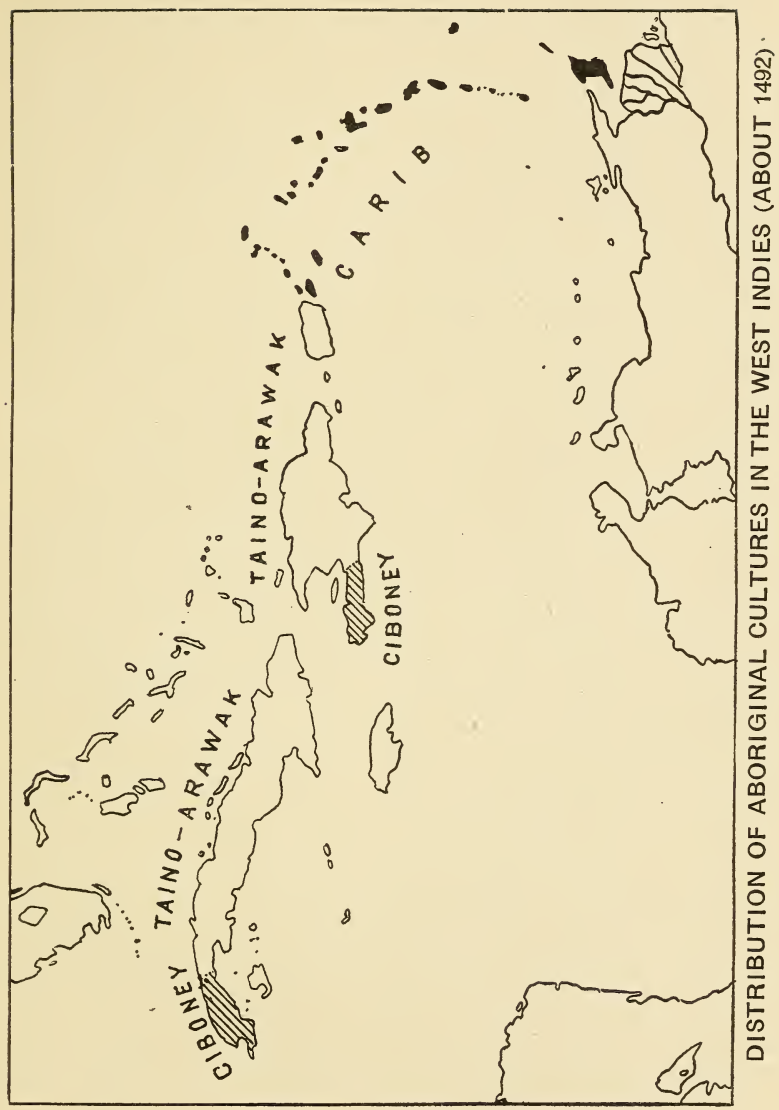





\begin{tabular}{|l|}
\hline T H I R D F L O O R \\
\hline are still found. The Arawak evidently \\
left South America first, and gradually \\
spread northward and westward, first \\
through the Lesser Antilles, then the \\
Greater, displacing the earlier inhabitants \\
where such existed, and confining them to \\
limited areas, as in Cuba. In the Greater \\
Antilles they developed the culture we know \\
as Taino; then a wave of Carib migration \\
started from South America and spread \\
through the Lesser Antilles. The Carib \\
seem to have exterminated the Arawak \\
bodily on some of these islands, while on \\
others they killed the men and captured \\
the women. When the caravels of Colum- \\
bus first sighted the New World, the Carib \\
had occupied all of the Lesser Antilles and \\
were already raiding Porto Rico and Haiti, \\
while the Taino were fast overrunning \\
Cuba, driving the Ciboney to the western \\
tip of the island and to the outlying keys. \\
The remains of the Taino-Arawak and \\
of the Ciboney have been studied and their \\
principal characteristics established; which \\
has not, unfortunately, been done with \\
any degree of completeness for the Carib. \\
\hline A N D M O N O G R A P H S
\end{tabular}




\begin{tabular}{|l|l|}
\hline 8 & \multicolumn{1}{|c|}{ G U I D E } \\
\hline $\begin{array}{l}\text { However, archeology reveals the presence } \\
\text { of three great cultures, and only three, } \\
\text { and Columbus and his successors found } \\
\text { three kinds of Indians inhabiting the West } \\
\text { Indies. Now, two of the archeological } \\
\text { cultures have already been identified as } \\
\text { belonging to two of the groups, the Taino } \\
\text { and the Ciboney, respectively, so we can } \\
\text { not go far wrong in attributing the third } \\
\text { culture to the third group, the Carib, } \\
\text { especially as the distribution of that culture } \\
\text { in the Antilles corresponds exactly with } \\
\text { the Carib habitat as described by the early } \\
\text { explorers. Indeed the results of archeologi- } \\
\text { cal research in all the West Indies, so far as } \\
\text { it has progressed, bear out to a remarkable } \\
\text { degree our historical knowledge of the dis- } \\
\text { tribution of the peoples in the region. } \\
\text { Thus in Cuba we find abundant remains } \\
\text { of the Ciboney and the Taino, while relics } \\
\text { of the culture attributed to the Carib are } \\
\text { rare indeed; the Bahamas, Haiti (or Santo } \\
\text { Domingo), and Jamaica have yielded } \\
\text { many Taino specimens, and a few of Carib } \\
\text { origin, while future examination may reveal } \\
\text { the crude remains of the Ciboney, whose }\end{array}$ \\
\hline \multicolumn{1}{|c|}{$\mathrm{I}$ N D I A N N O T E S } \\
\hline
\end{tabular}




\begin{tabular}{|l|}
\hline T H I R D F L O O R \\
\hline presence in Haiti is suggested by historical \\
evidence. Porto Rico yields mainly Taino \\
artifacts, but Carib traces are fairly abun- \\
dant; and the Lesser Antilles yield both \\
Arawak and Carib objects-sometimes one, \\
sometimes the other predominating, but \\
mainly the latter. Much more informa- \\
tion will be found in "Cuba Before Colum- \\
bus," published by the Museum. \\
THE TAINo TRIBES \\
THE term Taino has been adopted by \\
archeologists as a general designation for \\
the Arawak tribes of the Greater Antilles \\
which had developed a peculiar culture \\
of their own. The name is derived from \\
their own language, and means "good or \\
peaceable men," as contrasted with the \\
warlike and cannibalistic Carib. They \\
made their living largely by raising corn \\
or maize, cassava, and other native plants, \\
and by fishing; but hunting, on account \\
of the scarcity and the small size of most \\
of the land animals, did not attain great \\
importance. Most of their fishing was \\
accomplished with nets, while clubs, or \\
A N D M O N O G R A P H S
\end{tabular}




\begin{tabular}{|l|l|}
\hline 10 & \multicolumn{1}{|c}{ G U I D E } \\
\hline $\begin{array}{l}\text { macanas, and javelins were the favorite } \\
\text { weapons for hunting and for war. The } \\
\text { bow and arrow, though existing in some } \\
\text { localities, seem to have been little used by } \\
\text { these people. The canoes which furnished } \\
\text { them transportation were dug out from } \\
\text { single logs and were often well made and } \\
\text { large. These were propelled with pointed } \\
\text { paddles. } \\
\text { Their houses were circular or square in } \\
\text { groundplan, neatly made of poles thatched } \\
\text { with palm-leaves and walled with thin } \\
\text { sheets of bark-like material from certain } \\
\text { palm trees; their beds were hammocks } \\
\text { slung from the rafters. Very characteristic } \\
\text { were the stools or seats of wood, known as } \\
\text { duhos, often beautifully carved in human } \\
\text { or animal form and inlaid with shell, and } \\
\text { their handsomely decorated food vessels } \\
\text { of wood and of pottery. The boiling of } \\
\text { food was done in earthen pots set directly } \\
\text { over the fire, and baskets of various forms } \\
\text { and sizes, hung from the rafters, contained } \\
\text { surplus provisions, trinkets, and the like. } \\
\text { Peculiar graters made by driving in- } \\
\text { numerable bits of flint or other hard stone }\end{array}$ \\
\hline \multicolumn{1}{|c|}{$\mathrm{N}$ D I A N N O T E S } \\
\hline
\end{tabular}




\section{THIR D F L O O R}

into the surface of a slab of wood were used for grating cassava-root into meal, while for squeezing out the poisonous juices from the grated root to fit it for human food a basket press was employed. Both grater and press are still used by the related tribes in South America, while the presses are still remembered by surviving Cuban Indians, who have employed also the ancient type of grater until recently. After grating and pressing, the meal was made into thin loaves or cakes and baked on a flat circular griddle, made of pottery or stone, fragments of which are still abundant on the sites of the ancient villages.

For wood-cutting and similar purposes these tribes used hatchet-blades or "celts" of stone, some of them, especially the petaloid type, of unusual beauty in form and finish, mounted in club-like wooden handles; while fine cutting and carving of wood, bone, and shell were accomplished with knives, scrapers; and crude drills, rudely made from flakes of flint, their knowledge

\section{A ND MONOGRAPHS}




\begin{tabular}{|l|l|}
\hline 12 & \multicolumn{1}{|c|}{ G U I D E } \\
\hline $\begin{array}{l}\text { of flint-working falling far behind that of } \\
\text { other arts. Gritty stones were used for } \\
\text { smoothing the work when finished. } \\
\text { Clothing was little used, both men and } \\
\text { women going practically naked but for } \\
\text { tiny apron-like garments, such as are still } \\
\text { worn by their relatives in South America; } \\
\text { but a profusion of ornaments was employed, } \\
\text { including beads and pendants of stone, } \\
\text { shell, and bone, and circular earplugs of } \\
\text { shell. Doubtless suitable seeds and nuts, } \\
\text { and the feathers of tropical birds of brilliant } \\
\text { plumage were also widely employed as per- } \\
\text { sonal ornaments, as in South America. } \\
\text { The esthetic sense of the Taino was } \\
\text { best expressed in their carvings, especially } \\
\text { in wood and shell, the delicacy and symme- } \\
\text { try of the work in some cases being unsur- } \\
\text { passed in ancient America. The carvings } \\
\text { in bone and stone are cruder, but still show } \\
\text { a high degree of skill, as does much of the } \\
\text { pottery. Objects may be decorated with } \\
\text { purely geometric patterns, usually ovals or } \\
\text { intricate scroll-like designs, or with effigies } \\
\text { representing, in conventional form, men, }\end{array}$ \\
\hline \\
\begin{tabular}{l} 
I N D I A N N O T E S \\
\hline
\end{tabular}
\end{tabular}




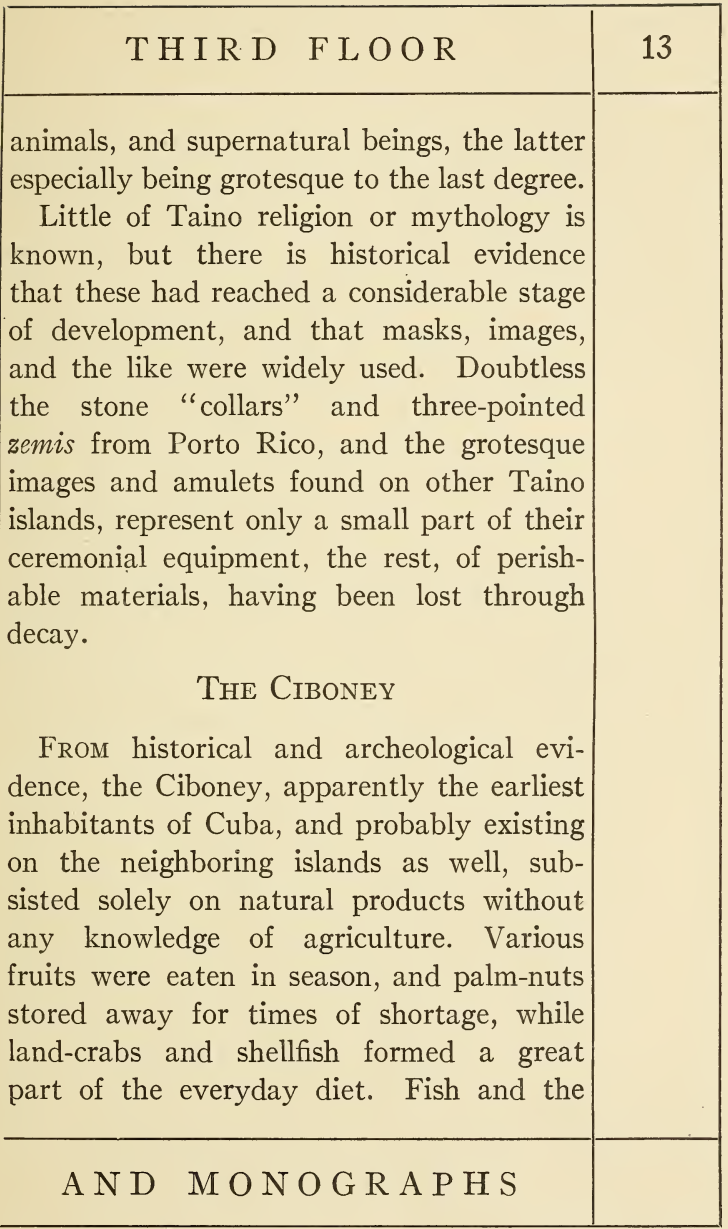




\begin{tabular}{|l|l|}
\hline 14 & \multicolumn{1}{|c|}{ G U I D E } \\
\hline $\begin{array}{l}\text { flesh of the jutia and other small animals } \\
\text { were also eaten; and there is some evidence } \\
\text { that the now extinct megalocnus, a huge } \\
\text { ground sloth, may have formed part of } \\
\text { Ciboney diet in ancient times. } \\
\text { There is no definite knowledge of their } \\
\text { weapons, but it is very probable that the } \\
\text { bow and arrow were numbered among } \\
\text { them. They seem to have made dugout } \\
\text { canoes of ruder construction than those of } \\
\text { the Taino. They occupied caves and rock- } \\
\text { shelters wherever possible, and in such } \\
\text { places their remains are frequently found; } \\
\text { but also on occasion lived in camps in the } \\
\text { open-probably in shelters of the rudest } \\
\text { kind. Most of their deposits show no trace } \\
\text { of pottery, but they seem to have had a } \\
\text { little after contact with the Taino. How- } \\
\text { ever this may be, they made bowls of wood } \\
\text { with the aid of fire, using gouges made of } \\
\text { conch-shell to scrape away the charcoal } \\
\text { as the work progressed, and turned conch- } \\
\text { shells into serviceable bowls and dippers } \\
\text { by pecking out the interior whorls and the } \\
\text { core. The stone mortars and pitted ham- } \\
\text { merstones employed by the Ciboney were }\end{array}$ \\
\hline I N D I A N N O T E S \\
\hline
\end{tabular}




\begin{tabular}{|l|l|}
\hline T H I R D F L O O R & 15 \\
\hline similar to those found throughout eastern \\
North America, but their work in flint was \\
very crude, consisting mainly of flake knives \\
and rough scrapers. Axes or celts of stone \\
and shell occur, but are rare and differ in \\
form from Taino types. \\
We know nothing of their dress, or lack \\
of it; their ornaments were disc beads \\
fashioned of shell or of fish vertebrae, and \\
pendants made from waterworn bits of \\
shell or stone, and of sharks' teeth, per- \\
forated for suspension. \\
The only specimen known that may \\
possibly illustrate the decorative art of the \\
Ciboney is a carved wooden baton found \\
in the mud of the bottom of a lake in \\
western Cuba. The design consists entirely \\
of dots and incised intersecting straight lines, \\
and although neatly made, cannot be com- \\
pared with the products of Taino art. It \\
may have been used in ceremonies. \\
Nothing else relating to their ceremonial \\
or religious life has apparently survived, \\
unless the Ciboney may have been respon- \\
sible for the exceedingly rude faces pecked \\
on stalagmites in certain Cuban caves. \\
\hline A N D M O N O G R A P H S
\end{tabular}




\begin{tabular}{|c|c|}
\hline 16 & G U I D E \\
\hline & $\begin{array}{l}\text { THE CARIB } \\
\text { As before stated, the Carib culture has } \\
\text { not yet been fully worked out and defined, } \\
\text { but we can be fairly certain that in general } \\
\text { features (excepting always their piratical } \\
\text { raids and their cannibalism, both character- } \\
\text { istically Carib) their mode of life, dwellings, } \\
\text { hammock-beds, use of cassava, and the } \\
\text { like, were quite similar to those of the Taino. } \\
\text { The Carib were expert bowmen, however, } \\
\text { which can not be said of the Taino, and } \\
\text { the archeologist observes that they were } \\
\text { much more given to painting their pottery } \\
\text { then were the Taino, especially in red, } \\
\text { black, and white; that the forms were } \\
\text { somewhat different, and that the effigies } \\
\text { used as handles and decorations for the } \\
\text { earthenware vessels have a fat, bloated } \\
\text { look not seen in Taino ware. The Carib, } \\
\text { moreover, preferred celts of ordinary type, } \\
\text { or notched or grooved stone axes, or axes } \\
\text { of fanciful form, to the petaloid celt-axe } \\
\text { characteristic of the Taino; in fact, when } \\
\text { petaloid celts are found on Carib islands } \\
\text { they are probably either relics of the orig- }\end{array}$ \\
\hline & I N I A N NOTES \\
\hline
\end{tabular}




\section{THIR D F L O R}

inal Arawak occupancy or were brought home as trophies by Carib raiders from Taino territory.

Carved wooden stools, idols of stone or wood, carved wooden platters, and stone collars, all familiar Taino artifacts, do not seem to have been made by the Carib, and are seldom seen in the Lesser Antilles, although the three-pointed zemis may have been occasionally imitated by them. It is also noticeable that beads, amulets, or personal ornaments of any kind, so abundant in Cuba, for example, are rare in Carib territory, and when they do occur are usually different in form-perhaps this people made such things mainly of perishable materials.

\section{ETHNOLOGY OF THE WEST INDIES}

(Case $316 \mathrm{~A}$ )

OwING to their enslavement and virtual extermination by the Spaniards shortly after the Discovery, but few persons showing Indian blood to a marked degree are left in the West Indies; yet some linger in

\section{A N D MONOGRAPHS}




\begin{tabular}{|c|c|}
\hline 18 & G U I D E \\
\hline & $\begin{array}{l}\text { Cuba, mostly in the eastern part, and in a } \\
\text { few of the other islands. Most of the } \\
\text { collection exhibited was obtained from } \\
\text { Yara village near Baracoa, Cuba, and from } \\
\text { scattered families in the Maisi district, } \\
\text { survivors of the Taino. Many of the arti- } \\
\text { cles shown are also used by the neighboring } \\
\text { country people of Spanish extraction, but } \\
\text { all seem to be of aboriginal origin. Some, } \\
\text { however, show modification due to Spanish } \\
\text { influence. Especial attention is called to } \\
\text { the cassava grater, made by driving bits } \\
\text { of hard stone into a wooden tablet. } \\
\text { On the lower shelf may be seen a few } \\
\text { articles made by the surviving Carib of } \\
\text { St. Vincent and Trinidad, and on the top } \\
\text { of Case } 329 \text { a raft or catamaran of native } \\
\text { type from the former island. } \\
\text { ARCHEOLOGY OF THE WEST } \\
\text { INDIES } \\
\text { CUBA } \\
\text { IN Cuba exploration by expeditions from } \\
\text { this Museum thus far has revealed two } \\
\text { principal cultures: (1) that of the primitive }\end{array}$ \\
\hline & INDIAN NOTES \\
\hline
\end{tabular}





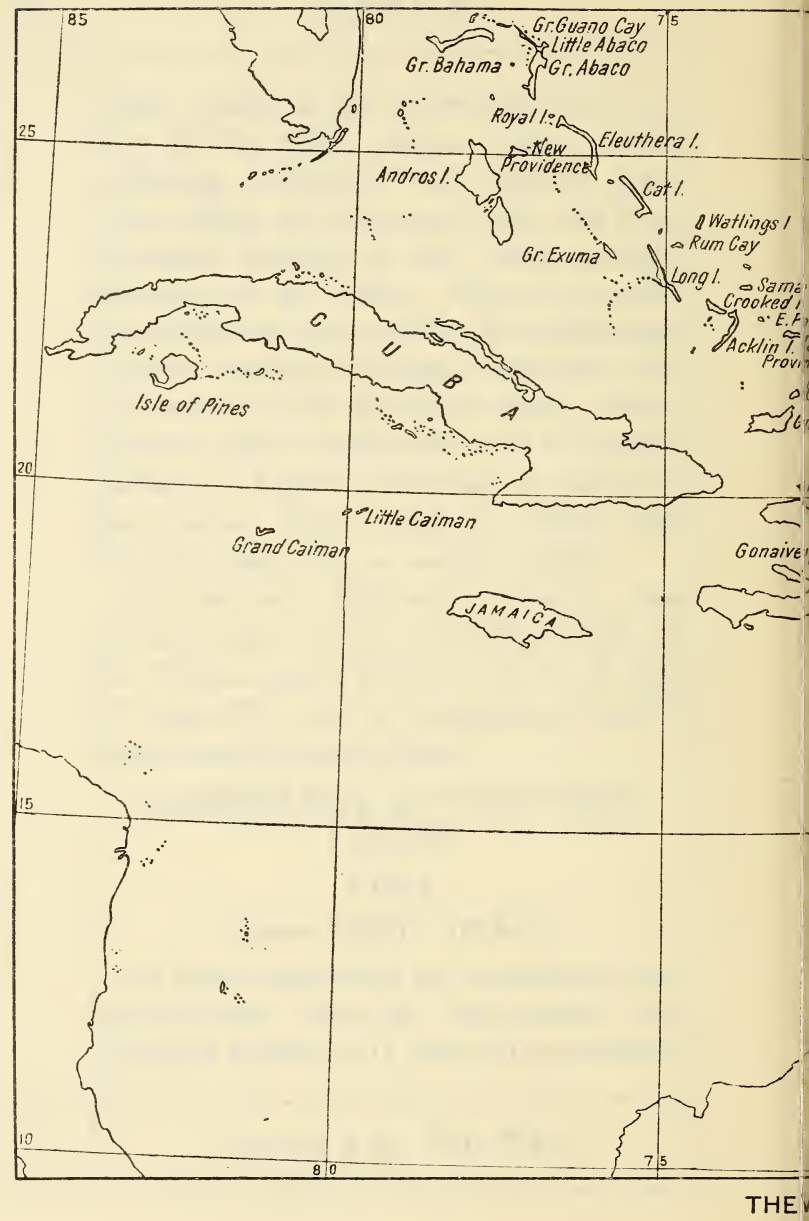





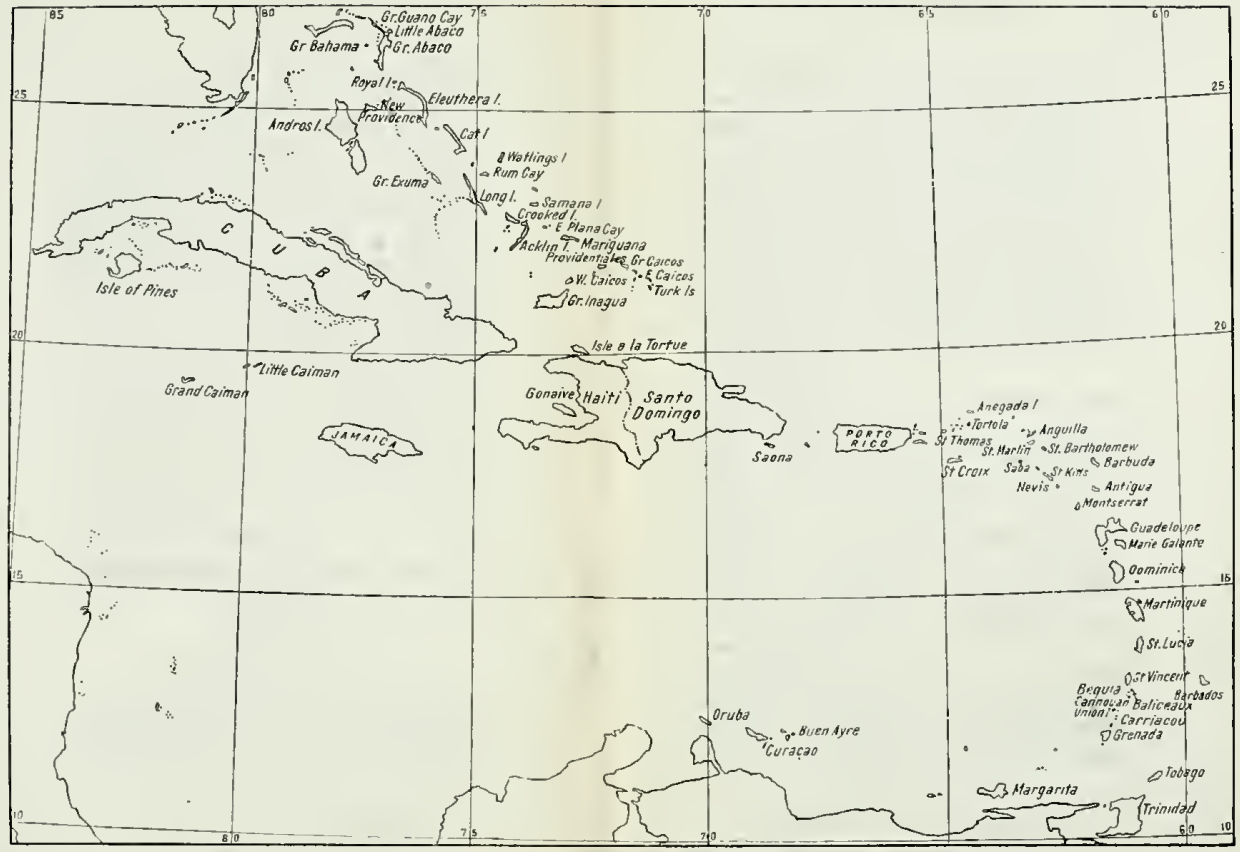

THE WEST INDIES 



\section{THIR D F L O R}

cave-dwelling Ciboney who were apparently the earliest inhabitants and lived in early times from one end of the island to the other; (2) that of the more advanced Taino who were long established only in the eastern end of the island, although just before the conquest they had overrun most of it. Thus it happens that although crude Ciboney specimens may be found in almost any part of Cuba, the remains of the Taino may be encountered in quantity only in the eastern portion.

Most of our Ciboney specimens were found buried in the floors of the caves where these people once lived, although some were discovered in the refuse-heaps marking their camp-sites. On the other hand, most of the Taino material in the Museum was exhumed from village-sites, and only occasional specimens-usually fine objects hidden for safekeeping-were found in caves.

Two full case panels and parts of two more are devoted to one of the most characteristic products of the Taino-their pottery. The range of form and design

\section{A ND MONOGRAPHS}




\begin{tabular}{|l|l|}
\hline 20 & \multicolumn{1}{|c}{ G U I D E } \\
\hline $\begin{array}{l}\text { used by the Cuban bands are well illus- } \\
\text { trated, especially the almost endless variety } \\
\text { of grotesque heads and figures used as } \\
\text { handles for the vessels. } \\
\text { Equally characteristic of the Taino are } \\
\text { the beautiful petaloid celts, of which a } \\
\text { representative series is displayed, beside } \\
\text { celts of forms which might have originated } \\
\text { anywhere, and various forms of hammer- } \\
\text { stones, pestles, and other stone implements. } \\
\text { The making of celts is illustrated by a series } \\
\text { showing them in all stages of manufacture, } \\
\text { together with the hammerstones used to } \\
\text { batter and grind them into shape. The } \\
\text { use of such celts as axes (hafted like the } \\
\text { specimen from North Caicos, Case 319 B) } \\
\text { is illustrated by a cut stick forming part of a } \\
\text { rack in a burial cave. Also of stone are } \\
\text { various fetishes, amulets, and beads, some } \\
\text { of them beautifully made, and a few pitted } \\
\text { stones, mortars, cassava griddles, weights, } \\
\text { and the like. Another characteristic Taino } \\
\text { art is illustrated by specimens of wood- } \\
\text { carving, including a paddle, part of an effigy } \\
\text { representing a cayman or crocodile, and a } \\
\text { beautifully carved platter, all found hidden }\end{array}$ \\
\hline \multicolumn{1}{|c|}{ I N D I A N N O T E S } \\
\hline
\end{tabular}




\section{THIR D FLOOR}

in caves for safekeeping. The last two of these have evidently been inlaid at some time with mother-of-pearl.

The shell carving of the Taino was often excellent, as may be seen by the amulets and ornaments in the exhibit, while a series of tools and unfinished objects show how the work was done.

Objects of bone are not so abundant, but in the collection exhibited some of the pieces (especially the part of a bone platter and the fragments of spoons and swallowsticks) exhibit considerable skill.

The coming of the Spaniards and the beginning of the written historical period in general are illustrated by two specimens only - a rusty iron spear-head and a crumpled piece of sheet-copper.

The shell vessels, shell gouges, mortars, and pitted hammerstones, characteristic of the primitive Ciboney from both ends of the island, may be seen in the last panel, together with their beads and simple ornaments, their rude flints, and a few examples of their woodwork. Of the last, the baton with a carved handle is especially worthy

\section{A N D MONOGRAPHS}




\begin{tabular}{|c|c|}
\hline 22 & G U I D E \\
\hline & $\begin{array}{l}\text { of notice, as perhaps the only surviving } \\
\text { example of Ciboney decorative art. This, } \\
\text { with several other wooden objects, was } \\
\text { found in the muck in the bottom of a lake } \\
\text { in Pinar del Rio. } \\
\text { A small number of potsherds exhibited } \\
\text { in this section, found in a few Ciboney } \\
\text { caves, may indicate that in later days the } \\
\text { primitive Ciboney people acquired some } \\
\text { knowledge of the potter's art, perhaps } \\
\text { from the invading Taino. } \\
\text { Of unknown origin are the crude faces } \\
\text { and figures on exhibition found carved on } \\
\text { stalagmites in certain caves. They were } \\
\text { probably used ceremonially, but whether } \\
\text { the Ciboney or the Taino made them is } \\
\text { impossible to say, although their rudeness } \\
\text { would suggest the former. } \\
\text { JAMAICA } \\
\text { (Case } 319 \text { A-D) } \\
\text { THE upper two shelves of Case } 319 \text { and } \\
\text { the space under it are devoted to a collec- } \\
\text { tion from Jamaica, all of which, except } \\
\text { perhaps several large stone mortars, and } \\
\text { the three-legged grinding stone or seat, }\end{array}$ \\
\hline & I N D A N NOTES \\
\hline
\end{tabular}




\section{T H I R D F L O R}

seems to be easily identified as Taino. This seat may have been imported from the mainland; the mortars are of unusually large size, but they resemble some Cuban Ciboney mortars in form.

An examination of the pottery reveals the fact that it bears a strong similarity to Cuban Taino ware, although somewhat simpler and cruder, on the whole, in form and design; the hatchets and ornaments are clearly similar to corresponding objects in Cuba.

Perhaps the slight inferiority noticeable in Jamaican Taino remains, as compared with those of the other islands, may be due to the fact that Jamaica is somewhat isolated, and was not in continual touch with the specialized development of Taino culture in Cuba, Haiti (Santo Domingo), Porto Rico, and the Bahamas.

The explorations by the Museum expedition to this island have been described in a publication "Certain Kitchen-middens in Jamaica."

\section{A N D MONOGRAPHS}




\begin{tabular}{|c|c|}
\hline 24 & G U I D E \\
\hline & $\begin{array}{l}\text { BAHAMAS } \\
\text { (Case 319A B) } \\
\text { A GLANCE at the collection from the } \\
\text { various islands of the great Bahama group } \\
\text { lying north of Cuba, the names of which } \\
\text { may be found on the accompanying map, } \\
\text { shows that their culture was indistin- } \\
\text { guishable from that of the Cuban Taino. } \\
\text { Here we have the typical Taino petaloid } \\
\text { celts, decoration on pottery, and amulets, } \\
\text { some of the latter better than any we have } \\
\text { from Cuba, and an excellent series of typical } \\
\text { wooden seats, or duhos, two of them adorned } \\
\text { with heads and one with intricate carvings } \\
\text { like those of the Cuban wooden platter. } \\
\text { Best of all is a fine petaloid celt with its } \\
\text { wooden handle still intact, found in a cave } \\
\text { on North Caicos island. That this was a } \\
\text { usual method of hafting these stone axes } \\
\text { may be seen from a monolithic hatchet } \\
\text { from Grand Caicos carved from a single } \\
\text { piece of stone to represent a petaloid stone } \\
\text { celt in a similar wooden handle. A similar } \\
\text { but. ruder one was found in Providenciales. } \\
\text { Suggesting the presence of the Ciboney } \\
\text { in the Bahamas are several shell gouges; }\end{array}$ \\
\hline & I N D A N NOTES \\
\hline
\end{tabular}




\begin{tabular}{|c|c|}
\hline THIRD FLOOR & 25 \\
\hline $\begin{array}{l}\text { and perhaps further investigation will } \\
\text { establish the fact of their presence in these } \\
\text { islands before the coming of the Taino. } \\
\text { The existence of a third and as yet unknown } \\
\text { culture is suggested by the finding, in the } \\
\text { Caicos group, of some extraordinary shell- } \\
\text { tempered potsherds, highly decorated with } \\
\text { incised straight lines and angles, unlike } \\
\text { anything found elsewhere in the West } \\
\text { Indies. } \\
\text { SANTO DOMINGO } \\
\text { (Cases } 318 \text { A-D, 321 A) } \\
\text { TuE island of Santo Domingo, anciently } \\
\text { called Haiti, and now occupied by the } \\
\text { republics of Santo Domingo and Haiti, } \\
\text { although only partially explored, has yielded } \\
\text { a large collection consisting, for the greater } \\
\text { part, of pottery and stonework, both to a } \\
\text { large degree obviously of Taino origin and } \\
\text { similar to the specimens found in Cuba and } \\
\text { the Bahamas. } \\
\text { Some of the pottery is better made than } \\
\text { the average Cuban ware, and there is an } \\
\text { even greater variety in form, yet the re- } \\
\text { semblance is very strong indeed. Special }\end{array}$ & \\
\hline AND MONOGRAPHS & \\
\hline
\end{tabular}




\begin{tabular}{|l|l|}
\hline 26 & \multicolumn{1}{|c|}{ G U I D E } \\
\hline \begin{tabular}{l} 
attention is called to the heart-shape water- \\
bottles, a type not seen in Cuba at all, \\
and the hollow human figures of earthen- \\
ware, perhaps used as idols, of which only \\
fragments were found in Cuba. Stamps \\
for applying paint, made of earthenware, \\
and in one case of stone, are abundant on \\
this island. \\
In stonework we have the little figurines \\
or amulets, the beads, the pestles, and the \\
petaloid celts characteristic of the Taino \\
culture in Cuba, but in addition we find \\
zemis, or "three-pointed fetishes," in the \\
form of the human breast, which are thought \\
to represent the God of Food or of Fertility; \\
and the curious massive objects of stone, \\
shaped like horse-collars, also thought to \\
be fetishes. These last two classes of \\
objects are especially characteristic of the \\
Taino bands of Porto Rico. \\
Other noteworthy specimens in stone \\
are a unique dagger or club, a carving \\
representing a monkey, once apparently \\
attached to a staff or handle of wood, a \\
large flint implement, and two T-shape \\
stones of unknown use. \\
\hline \multicolumn{1}{|c|}{ I N D I A N N O T E S }
\end{tabular} \\
\hline
\end{tabular}


Exhibited also are a few objects of shell and bone suggesting those of Cuba, and a small but interesting wooden idol, all typically Taino.

Carib culture is represented in the collection from this island only by a few axe. heads and perhaps the T-shape stones, and the Ciboney not at all; but further exploration will probably supply specimens of both, especially the latter.

The results of two expeditions to this island have been published by the Museum.

\section{PORTO RICO}

(Cases $321 \mathrm{~B}, 322 \mathrm{~A}$ )

IN the Porto Rico exhibit we see the massive stone collars and the mammiform zemis, before mentioned, as being the most characteristic of Taino products for this island, although found occasionally in Santo Domingo, and, rarely, in the Lesser Antilles.

As before stated, the zemis, or threepointed stones, most of them made in the form of the human breast, probably represent the God of Food or of Fertility, or

\section{A N D MONOGRAPHS}




\begin{tabular}{|l|l|}
\hline 28 & \multicolumn{1}{|c|}{ G U I D E } \\
\hline $\begin{array}{l}\text { maybe Mother Earth from whom the tribes } \\
\text { of men draw their food as the infant does } \\
\text { from its mother's breast. They seem to } \\
\text { have been considered powerful in produc- } \\
\text { ing large crops of yuca or cassava. } \\
\text { It is thought that the curious objects of } \\
\text { stone resembling horse-collars, like the } \\
\text { three-pointed stones, were zemis or fetishes } \\
\text { used in tree-worship, and that the earliest } \\
\text { forms were of wood, made by bending a } \\
\text { root or a pole into the form of an oval } \\
\text { hoop and fastening the ends together. A } \\
\text { more highly developed form was appar- } \\
\text { ently compound, combining a wooden hoop } \\
\text { with a so-called "elbow-stone," of which } \\
\text { we exhibit some specimens, while the final } \\
\text { stage was the collar, made entirely of stone, } \\
\text { but still showing in many cases an attempt } \\
\text { to represent characteristics of the wooden } \\
\text { original. } \\
\text { Much of the pottery is thoroughly Taino } \\
\text { in character and might have come from } \\
\text { Santo Domingo or Cuba, but Carib in- } \\
\text { fluence is seen in the red-painted ware and } \\
\text { in the forms of some of the grotesque heads } \\
\text { used as handles for vessels. }\end{array}$ \\
\hline I N D I A N N O T E S \\
\hline
\end{tabular}




\begin{tabular}{|c|c|}
\hline THIRD FLOOR & 29 \\
\hline $\begin{array}{l}\text { Most of the stone axes in the collection } \\
\text { from this island are either typical Taino } \\
\text { petaloid celts or celts of more widely dis- } \\
\text { tributed forms; the stone beads and the } \\
\text { like resemble those of Cuba. Especially } \\
\text { worthy of note is the } d u h o \text {, or wooden seat, } \\
\text { the back of which is higher than usual, and } \\
\text { a tiny duho of stone made to represent } \\
\text { the wooden type. } \\
\text { No trace of the Ciboney culture is seen } \\
\text { in the collection, unless the few rude celt- } \\
\text { like implements of shell may be attributed } \\
\text { to them. }\end{array}$ & \\
\hline $\begin{array}{l}\text { VIRGIN ISLANDS } \\
\text { (Cases } 322 \mathrm{~B}, 324 \mathrm{~B})\end{array}$ & \\
\hline $\begin{array}{l}\text { THE Virgin Islands, including St Thomas, } \\
\text { St Croix, St John, and Tortola, recently } \\
\text { acquired by the United States, have yielded } \\
\text { to a Museum expedition a collection illus- } \\
\text { trating both the Arawak and the Carib } \\
\text { cultures, the former doubtless represent- } \\
\text { ing the earlier occupancy, as the Carib } \\
\text { seem to have been in full possession at } \\
\text { the time of the Discovery. The rather } \\
\text { crude character of the Arawak pottery }\end{array}$ & \\
\hline A ND MONOGRAPHS & \\
\hline
\end{tabular}




\begin{tabular}{|l|l|}
\hline 30 & \multicolumn{1}{|c|}{ G U I D E } \\
\hline $\begin{array}{l}\text { would indicate this, too-it seems to } \\
\text { represent a period before the Taino cul- } \\
\text { ture had attained the height of its develop- } \\
\text { ment. Much of the pottery found on these } \\
\text { islands is so plain, however, that it lacks } \\
\text { distinguishing features serving to determine } \\
\text { its origin. The distinctly Carib ware is } \\
\text { recognizable as usual by its decoration in } \\
\text { red or in red and white, and by the form } \\
\text { of the grotesque heads. Especially in- } \\
\text { teresting are several massive Carib bowls } \\
\text { showing painted decoration on the inside. } \\
\text { One Taino stone collar was collected on } \\
\text { St. Croix island, but this was probably a } \\
\text { trophy from Porto Rico brought home by } \\
\text { Carib raiders; and there are also two small } \\
\text { rude mammiform zemis of Taino style. } \\
\text { The stone axes show both the grooved } \\
\text { and the notched forms of the Carib, the } \\
\text { fine petaloid celts of the Arawak, and a } \\
\text { number whose origin is doubtful. } \\
\text { There are several objects of bone in the } \\
\text { collection also-one of them the handle, } \\
\text { carved in the form of a man, of some im- } \\
\text { plement, probably a "swallow-stick," such } \\
\text { as was thrust down the throat in certain }\end{array}$ \\
\hline $\begin{array}{l}\text { I N D I A N N O T E S } \\
\text { and }\end{array}$ \\
\hline
\end{tabular}




\section{T H I R D F L O R}

ceremonies. This has inlaid shell eyes and mouth, and is an excellent specimen of Taino art.

The Ciboney are not represented in the collection, unless it may be that they made the shell celts displayed. It will take further exploration and study to determine whether this was the case, or whether the implements in question were the work of the Arawak or the Carib. It seems probable, however, in view of their increase in number as we pass down through the islands, that they are of Carib origin.

Further information may be found in "Archeology of the Virgin Islands," published by this Museum.

\section{OTHER ISLANDS}

\section{(Case $324 \mathrm{~A} \mathrm{~B}$ )}

From Anguilla and St Eustatius the collection is small and has little character. From St. Kitts and Nevis most of the axes and pestles have a Carib appearance. Montserrat yields Carib stone implements, and decidedly Carib polychrome pottery, with one tiny three-pointed zemi of Arawak

\section{A N D MONOGRAPHS}




\begin{tabular}{|c|c|}
\hline 32 & G U I D E \\
\hline & $\begin{array}{l}\text { origin, or showing the influence of that } \\
\text { people. On the other hand, we see two } \\
\text { decidedly Arawak petaloid celts in the } \\
\text { Antigua collection, and the four objects } \\
\text { from St Martin include one fine Taino } \\
\text { zemi. } \\
\text { GUADALOUPE AND DOMINICA } \\
\text { (Case } 324 \text { A) } \\
\text { THE larger collection from Guadaloupe, } \\
\text { mainly stone axes, consists on the whole } \\
\text { of distinctly Carib types; and here we first } \\
\text { note the ornate forms of stone axe-heads } \\
\text { so highly developed farther south; and the } \\
\text { same may be said of the Dominica collec- } \\
\text { tion. In this the only object suggesting } \\
\text { the possibility of Arawak origin is a solitary } \\
\text { three-pointed zemi, and this may be merely } \\
\text { a Carib imitation. } \\
\text { MARTINIQUE } \\
\text { (Case } 324 \text { B) } \\
\text { THE small collection from this island } \\
\text { shows the Arawak petaloid celt and the } \\
\text { Carib grooved or notched axe side by side. }\end{array}$ \\
\hline & I N I A N N T E S \\
\hline
\end{tabular}




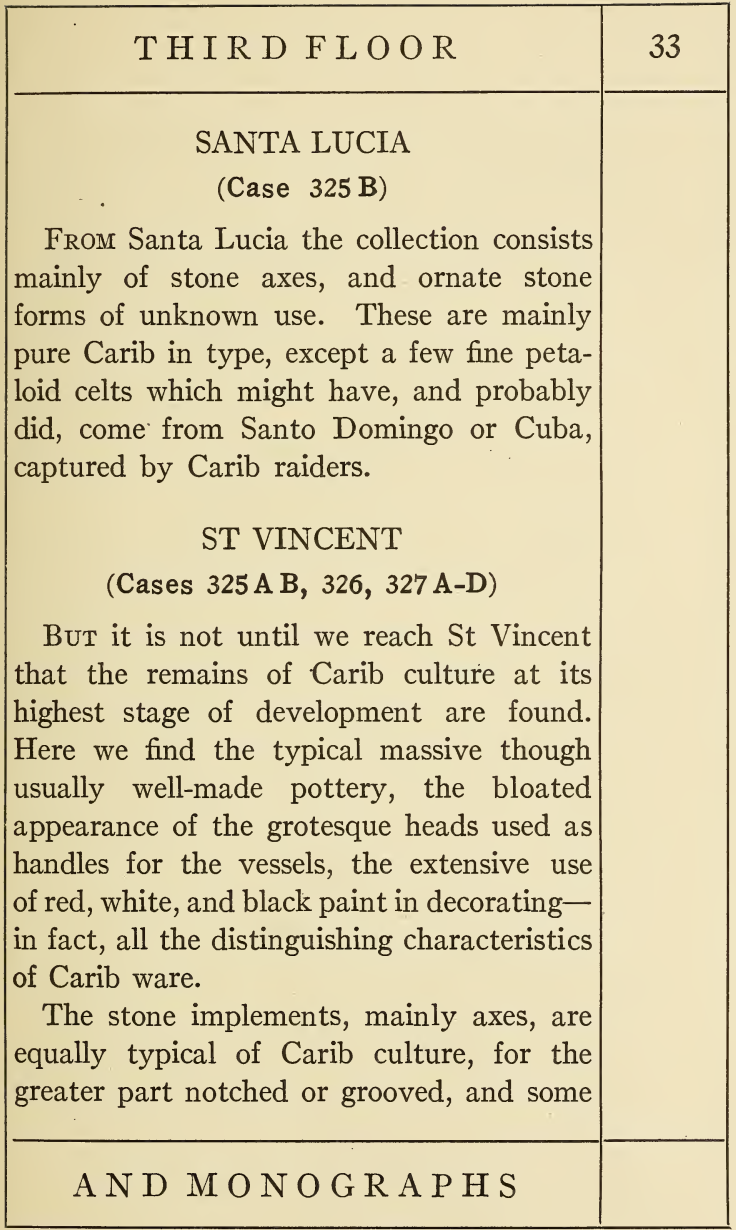




\begin{tabular}{|l|l|}
\hline 34 & \multicolumn{1}{|c|}{ G U I D E } \\
\hline $\begin{array}{l}\text { of them ornamented with decorative pro- } \\
\text { tuberances of varying forms. One espe- } \\
\text { cially ornate specimen, doubtless intended } \\
\text { for ceremonial use, shows a carved open- } \\
\text { work decoration on the poll, and others, } \\
\text { effective designs on the blades. A hand- } \\
\text { some decorated dish of stone also figures } \\
\text { in the collection. } \\
\text { There are also a number of crescent-shape, } \\
\text { hook-like, and fanciful forms of stone to } \\
\text { which no practical use can be assigned, } \\
\text { although they are made of material hard } \\
\text { enough to stand service as implements. } \\
\text { Also exhibited is one entire case (326) filled } \\
\text { with fanciful forms in stone too soft to have } \\
\text { been of practical service for any purpose. } \\
\text { Some of these represent the well-known } \\
\text { axe-forms of the island, some the stone } \\
\text { dishes, while others are entirely fanciful. } \\
\text { They were found for the greater part in a } \\
\text { single locality, and, it is thought, formed } \\
\text { part of a ceremonial deposit of some sort. } \\
\text { Before leaving the subject of stone ob- } \\
\text { jects, attention is called to the large mortars } \\
\text { and grinding slabs, and the huge axe-heads } \\
\text { too large for practical use, all exhibited }\end{array}$ \\
\hline \multicolumn{1}{|c|}{$\mathrm{N}$ D I A N N O T E S } \\
\hline
\end{tabular}


beneath Case 327; also to the beads and amulets of stone which in most cases differ markedly from those of the Taino.

The only objects suggesting Taino styles in the collection are a few fine petaloid celts, perhaps brought home as war trophies, and some small three pointed zemis, probably imitations of Taino forms.

\section{GRENADINES}

(Case $328 \mathrm{~A}-\mathrm{D}$ )

The collection from the Grenadine islands including Baliceaux, Cannouan, Mustique, Bequia, Carriacou, Union I., and Little Martinique, shows practically the same culture as St Vincent, for the greater part typically Carib, with the exception of two three-pointed zemis of Taino type, and a few petaloid celts.

The island of Cannouan, however, has yielded some exceedingly rude axe-like implements that suggest the presence of another and very primitive culture which should be further investigated.

Special attention is called to the curiously grotesque water-bottle of pottery from the

\section{A N D MONOGRAPHS}




\begin{tabular}{|c|c|}
\hline 306 & G U I D E \\
\hline & $\begin{array}{l}\text { island of Carriacou. Shell celts seem quite } \\
\text { numerous in these islands, but their origin } \\
\text { is as yet uncertain. } \\
\text { GRENADA } \\
\text { (Case } 329 \mathrm{~A} \text { B) } \\
\text { IN Grenada the Carib culture is found } \\
\text { still in its most exuberant form, with axes } \\
\text { and pottery, exactly as in St Vincent, and } \\
\text { here too are found abundant shell celts } \\
\text { and occasional highly polished Taino } \\
\text { petaloids. As in Cannouan, there are a } \\
\text { few exceedingly crude axe-like implements } \\
\text { suggesting a former primitive culture. } \\
\text { Another noticeable feature is the presence } \\
\text { of several true adze-blades of stone with } \\
\text { one flat and one convex side, an implement } \\
\text { seen only occasionally on other Carib } \\
\text { islands and not at all in the Taino district. } \\
\text { TRINIDAD } \\
\text { (Case } 333 \mathrm{~A} \text { B) } \\
\text { islands and nearest the South American } \\
\text { coast, we still find Carib pottery at its }\end{array}$ \\
\hline & INDIAN NOTES \\
\hline
\end{tabular}


highest point of development, but our collection contains fewer of the typical Carib axes, and a new form, but rarely seen in the other Carib islands, appears here - an axe with two sharply cut notches near the poll-a type characteristic of Venezuela and the Guianas. Attention is called to the excellent series of complete or nearly complete Carib pottery vessels, especially a unique bird-shape water-bottle.

The results of two expeditions to this island have been published by the Museum.

\section{TOBAGO}

(Case $329 \mathrm{C}$ )

ONE would expect the island of Tobago, lying fairly near to Trinidad, to yield a full series of Carib artifacts, but such is not the case. The collection, on the contrary, comprises a large number of celts, including the petaloid, with very few axes recognizable as Carib, and no pottery at all, while a plummet-like stone implement, not seen elsewhere in the islands, appears.

\section{A N D MONOGRAPHS}




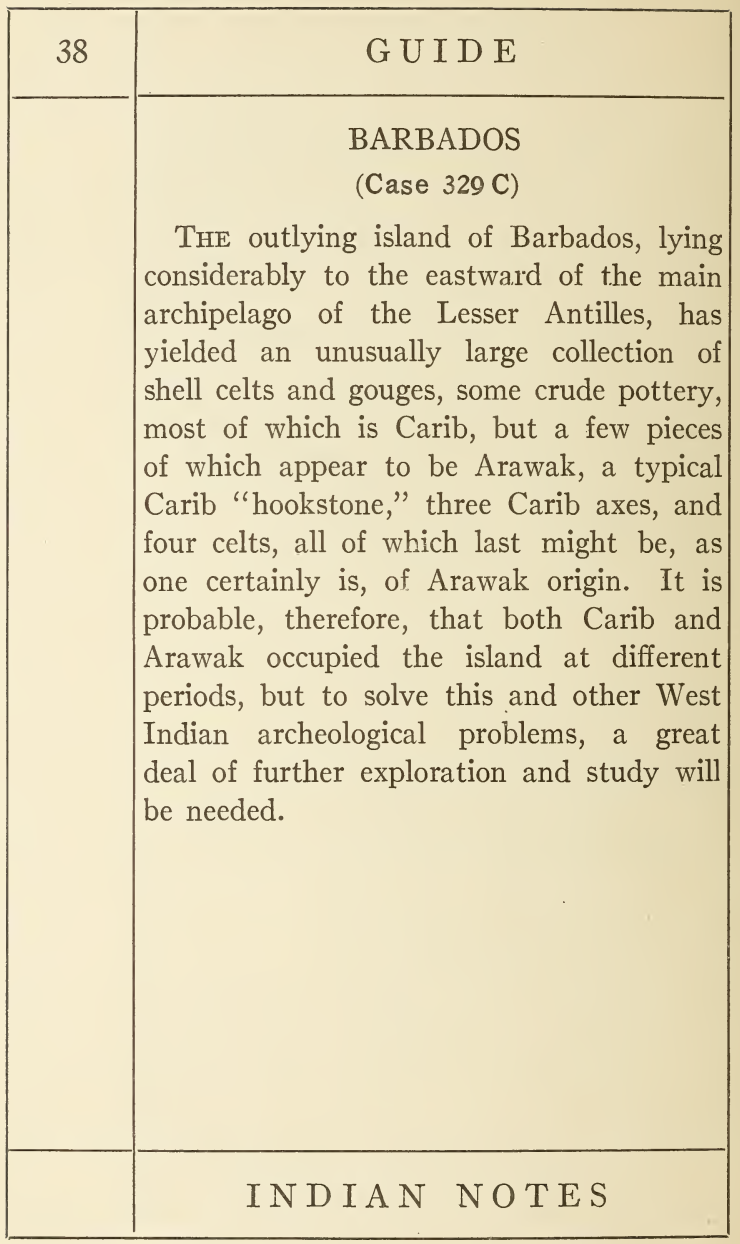




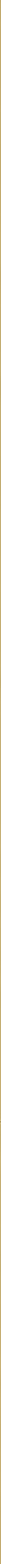


SMITHSONIAN INSTITUTION LIBRARIES

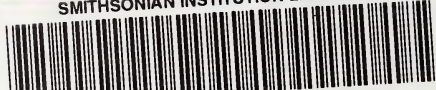

